\title{
In Vitro Hypoxia Increases Production of Matrix Metalloproteinases and Tryptase in Isolated Rat Lung Mast Cells
}

\author{
H. MAXOVÁ ${ }^{1,6}$, J. NOVOTNÁ ${ }^{2,6}$, L. VAJNER ${ }^{3}$, H. TOMÁŠOVÁ ${ }^{6}$, R. VYTÁŠEK ${ }^{2,6}$, \\ M. VÍZEK ${ }^{1,6}$, L. BAČÁKOVÁ ${ }^{5,6}$, V. VALOUŠKOVÁ ${ }^{4,6}$, T. ELIÁŠOVÁ ${ }^{6}$, J. HERGET ${ }^{4,6}$ \\ ${ }_{3}^{1}$ Department of Pathological Physiology, ${ }^{2}$ Dẹpartment of Medical Chemistry and Biochemistry, \\ 3 Department of Histology and Embryology, Department of Physiology, Second Medical School, \\ Charles University, Prague, ${ }^{5}$ Institute of Physiology, Academy of Sciences of the Czech Republic \\ and ${ }^{6}$ Centre for Cardiovascular Research, Prague, Czech Republic
}

Received May 5, 2007

Accepted September 17, 2007

On-line November 30, 2007

\section{Summary}

Chronic hypoxia results in hypoxic pulmonary hypertension characterized by fibrotization and muscularization of the walls of peripheral pulmonary arteries. This vessel remodeling is accompanied by an increase in the amount of lung mast cells (LMC) and the presence of small collagen cleavage products in the vessel walls. We hypothesize that hypoxia activates LMC, which release matrix metalloproteinases (MMPs) cleaving collagen and starting increased turnover of connective tissue proteins. This study was designed to determine whether in vitro hypoxia stimulates production of MMPs in rat LMC and increases their collagenolytic activity. The LMC were separated on the Percoll gradient and then were divided into two groups and cultivated for $24 \mathrm{~h}$ in $21 \% \mathrm{O}_{2}+5 \% \mathrm{CO}_{2}$ or in $10 \% \mathrm{O}_{2}+5 \%$ $\mathrm{CO}_{2}$. Presence of the rat interstitial tissue collagenase (MMP-13) in LMC was visualized by immunohistological staining and confirmed by Western blot analysis. Total MMPs activity and tryptase activity were measured in both cultivation media and cellular extracts. Exposure to hypoxia in vitro increased the amount of cells positively labeled by anti-MMP-13 antibody as well as activities of all measured enzymes. The results therefore support the concept that LMC are an important source of increased collagenolytic activity in chronic hypoxia.
\end{abstract}

\section{Key words}

Hypoxia in vitro • Rat lung mast cells • Tissue metalloproteinases

- Tryptase $\bullet$ Remodeling of pulmonary vessels

\section{Corresponding author}

H. Maxová, Department of Pathological Physiology, Second Medical School, Charles University, Plzeňská 221, 15000 Prague 5, Czech Republic. Fax: +420 257210995. E-mail: hana.maxova@lfmotol.cuni.cz

\section{Introduction}

Chronic hypoxia induces structural remodeling of pulmonary vessels. Connective tissue fibers are deposited and vascular smooth muscle cells are accumulated in the walls of pulmonary prealveolar vessels. We previously suggested that an increase in collagenolytic activity in the walls of the peripheral pulmonary arteries, which results in a presence of small collagen cleavage products (Novotná and Herget 1998), is one of the important triggering mechanisms of vascular remodeling induced by hypoxia (Hampl and Herget 2000, Novotná and Herget 2002). It is known that low molecular weight cleavage products of matrix proteins ("matrikines") initiate the fibroproduction and mesenchymal cell proliferation (Li et al. 2000). Collagen breakdown is a result of increased activity of matrix metalloproteinases (MMPs). In the rat species, the cleavage of native collagen starts by MMP-13, i.e. a rodent-like interstitial collagenase (Freije et al. 1994), and then continues by the activation of MMPs cascade including MMP-2, MMP-9 and other collagenolytic enzymes (Novotná and Herget 2002). Although the source of MMPs is not clear, the lung mast cells (LMC) are the most likely candidates. The number of LMC increases in chronic hypoxia (Kay et al. 1974, Vajner et al. 2006) and they express collagenolytic enzymes (Tozzi et al. 1998).

In order to elucidate the role of LMC in the early phase of chronic hypoxia, we tested whether in vitro 
hypoxia stimulates production of MMPs and tryptase in the mast cells isolated from rat lungs.

\section{Materials and Methods}

\section{Mast cell donors and experiment setting}

Twenty adult male Wistar specific pathogen-free rats (Anlab, Prague, Czech Republic) weighing from 320 to $360 \mathrm{~g}$ were used. Experiments were performed in accordance with the European Community and NIH guidelines for using experimental animals. All procedures were approved by our institution's Animal Studies Committee.

LMC were obtained in five separate isolations (lungs from four animals were used on single isolation). Each set of cells was divided in two portions. The cells of the first part were cultivated for $24 \mathrm{~h}$ in $21 \% \mathrm{O}_{2}+5 \%$ $\mathrm{CO}_{2}$ (control normoxic group $\mathrm{N}$ ), while the cells of the second portion were kept for the same time in hypoxia $\left(10 \% \mathrm{O}_{2}+5 \% \mathrm{CO}_{2}\right.$, group $\left.\mathrm{H}\right)$. At the end of the exposure we determined the change in MMP-13 formation as the change in relative count of the MMP-13 positive staining cells. Presence of MMP-13 and gelatinases (MMP-2 and MMP-9) were assayed in the cellular extracts by Western blot and zymography, respectively. Total MMPs and tryptase activities were measured in both cultivation media and in extracts from the cells.

\section{Chemicals for mast cells isolation}

Phosphate-buffered saline (PBS) solution (137 mM NaCl; $2.7 \mathrm{mM} \mathrm{KCl} ; 4.3 \mathrm{mM} \mathrm{Na} \mathrm{HPO}_{4}$; $1.47 \mathrm{mM} \mathrm{KH}_{2} \mathrm{PO}_{4}$ ), adjusted to $\mathrm{pH}$ 7.3; Eagle Minimum Esential Medium (E-MEM; Sevapharma, Prague, Czech Republic); cultivation medium RPMI-1640 (Sigma, Prague, Czech Republic) supplemented with $5 \%$ fetal calf serum, $10 \mathrm{mM}$ HEPES and $50 \mu \mathrm{g} / \mathrm{ml}$ Gentamicin (Lek Pharmaceuticals, Ljubljana, Slovenia); Trypan blue and Toluidine blue (Sigma); Thiopental (ICN Czech Republic, Roztoky, Czech Republic); Heparin (Léčiva, Prague, Czech Republic).

All enzymes - $2 \%$ trypsin (Sevapharma), collagenase (type I), elastase (type I, porcine pancreatic), hyaluronidase (type Is) and DNAse - were obtained from Sigma. Isotonic Percoll solution with a desired density of $1.11 \mathrm{~g} / \mathrm{ml}$ was prepared by dissolving $20 \mathrm{ml}$ of Percoll (300 mOsm $/ \mathrm{kg} \mathrm{H}_{2} \mathrm{O}$ ) (Sigma), $2.5 \mathrm{ml}$ of distilled water and $2.5 \mathrm{ml}$ of $1.5 \mathrm{M} \mathrm{NaCl}, \mathrm{pH}$ was adjusted to 7.4. Preformed continuous Percoll gradient was prepared by centrifugation (running conditions: rotor JA 25.50, $30000 \mathrm{x}$ g for $30 \mathrm{~min}, 7^{\circ} \mathrm{C}$ ). The density marker beads (Sigma) were used as external markers in a centrifuge tube containing identical gradient material to the one used for the experiment sample.

\section{Mast cell isolation procedure}

Rats were anesthetized by intraperitoneal injection of Thiopental (40 $\mathrm{mg} / \mathrm{kg})$ intubated and ventilated with positive pressure. Heparin $(0.2 \mathrm{ml}$, $1250 \mathrm{UI} / \mathrm{ml}$ ), was administered intracardially and lungs were perfused via pulmonary artery with $50 \mathrm{ml}$ PBS with a peristaltic perfusion pump at a rate of $4 \mathrm{ml} / 100 \mathrm{~g}$ of rat body weight $/ \mathrm{min}$. The lungs and trachea were excised en block, washed in PBS and lavaged 6 times by $4 \mathrm{ml}$ PBS. The trachea and major bronchi were removed and lungs were cut into 1-2 mm fragments. The minced tissue was three times washed by $60 \mathrm{ml}$ PBS. Tissue with $18 \mathrm{ml}$ PBS and $2 \mathrm{ml} 2 \%$ trypsin was shaken for $15 \mathrm{~min}$ and washed out by MEM. Then it was incubated for $45 \mathrm{~min}$ at $37{ }^{\circ} \mathrm{C}$ in an enzymatic mixture containing collagenase $(0.01 \mathrm{~g})$, hyaluronidase $(0.005 \mathrm{~g})$ and elastase $(0.25 \mathrm{ml})$ in $20 \mathrm{ml}$ MEM. Remaining intact tissue was disrupted by repeat passage through a syringe and DNAse $(0.001 \mathrm{~g}$ in $10 \mathrm{ml}$ MEM) was added for $10 \mathrm{~min}$. Then the digested tissue in $70 \mathrm{ml}$ MEM with $10 \mathrm{ml}$ serum was stepwise filtered through the mesh and $70 \mu \mathrm{m}$ pore size sifter. All harvested cells were twice centrifuged at $2000 \mathrm{x} \mathrm{g}$ for $10 \mathrm{~min}$. The embedded cells were resuspended at $4 \mathrm{ml}$ of PBS, layered onto the preformed continuous Percoll gradient and centrifuged at $400 \mathrm{x}$ g at $7^{\circ} \mathrm{C}$ for $30 \mathrm{~min}$.

A centrifugation fraction (1.102-1.119 $\mathrm{g} / \mathrm{ml}$ densities) containing mast cells was collected. This fraction was diluted in $15 \mathrm{ml}$ of cultivation medium RPMI-1640 and centrifuged at $300 \mathrm{x} \mathrm{g}$ for $30 \mathrm{~min}$. The sedimented cells were dispersed in $1 \mathrm{ml}$ of cultivation medium, and their number and vitality were assessed by trypan blue staining. To identify the mast cells (redpurple metachromatic heparin and histamine granules) toluidine blue staining was used.

\section{Mast cells cultivation and exposure to in vitro hypoxia}

Cells were seeded in Lab-Tek Chamber Slide System (177402 Nunc) with eight wells (50 000 cells per well), and $0.2 \mathrm{ml}$ of cultivation medium supplemented with $5 \%$ fetal calf serum was added into each well. Both groups of cells were allowed to recover at $37{ }^{\circ} \mathrm{C}$ in air + $5 \% \mathrm{CO}_{2}$ for $24 \mathrm{~h}$ in a cell incubator. Then the cells were put in the glass bottles (2 1) purged with normoxic (21\% 
$\left.\mathrm{O}_{2}+5 \% \mathrm{CO}_{2}\right)$ or hypoxic mixture $\left(10 \% \mathrm{O}_{2}+5 \% \mathrm{CO}_{2}\right)$ for $10 \mathrm{~min}$ with flow rate $3 \mathrm{l} / \mathrm{min}$ (Gas Mixer Pegas 4000 $\mathrm{MF}$, Columbus Instruments, Ohio, USA) and cultivated for next $24 \mathrm{~h}$ at $37{ }^{\circ} \mathrm{C}$. Partial pressures $\mathrm{pO}_{2}$ and $\mathrm{pCO}_{2}$ were measured in liquid samples by a radiometer (Radiometer Medical A/S IDK-2700, Copenhagen, Denmark) at the end of $24 \mathrm{~h}$ normoxic or hypoxic period.

The cultivation media were collected and frozen. Remaining cells were processed in three ways. One portion of the cells was fixed and used for immunohistochemical examination. Second one was frozen in PBS and stored for further experiments. The third portion served for obtaining mediators from the granules of the mast cells. For this purpose, the mast cell degranulation was stimulated by calcium ionophore A23187 (Sigma; $5 \mu \mathrm{g} / \mathrm{ml}$ in serum-free culture medium for $2 \mathrm{~h}$ at $37^{\circ} \mathrm{C}$ ). Yielded cellular extracts were then collected and frozen, too.

\section{Histology and immunohistochemistry}

The mast cells were cultured on chamber slides, and fixed with methanol. After blocking the endogenous alkaline phosphatase (AP) with levamizole and the nonspecific binding with $10 \%$ bovine serum albumin (BSA) in Tris-buffered saline (TBS), the slides were incubated with the monoclonal anti-MMP-13 antibody for $24 \mathrm{~h}$ at the room temperature in a humid chamber. Anti-MMP-13 monoclonal antibody was prepared in our laboratory. Briefly, the antibody was obtained as the ascitic fluid of mice BALB/c. The antigen, i.e. rat MMP-13, was prepared using affinity chromatography (Tyagi and Cleutjens 1996). Its identity was confirmed by immunoblotting using a standard of MMP-13 proenzyme (His. Tag, Human, Recombinant, Spodoptera frugiperda; Calbiochem). The antigen was diluted with TBS (1:50). As a secondary antibody, rabbit anti-mouse polyclonal AP-labeled (Sigma), diluted 1:50 with TBS, was used in the second step for $30 \mathrm{~min}$. The binding reaction was visualized using Fast Red TR/Naphthol AS-MX Sigma FAST tablets (Sigma). Cells were counterstained with hematoxylin and mounted in gelatin. In staining control samples, the primary antibody was omitted. MMP-13 positive and negative cells ratios (expressed as percentage share of positive cells) was counted in 36 assays from five separate isolations.

\section{Immunofluorescence microscopy}

Cells fixed in methanol stored at $-20{ }^{\circ} \mathrm{C}$ were washed for $10 \mathrm{~min}$ in PBS. Incubation with primary antibodies Anti-MMP-13 (Ab-6) Mouse (Calbiochem) diluted in PBS was carried out for $2 \mathrm{~h}$ at a room temperature. The slides were then rinsed by PBS three times for $5 \mathrm{~min}$ and cells were subsequently incubated with secondary antibodies Alexa Fluor $488 \quad \mathrm{~F}\left(\mathrm{ab}^{\prime}\right) 2$ fragment of Goat Anti-Mouse IgG (Invitrogen) for $30 \mathrm{~min}$ and rinsed. Propidium Iodide (Calbiochem) nucleic stain was added for $1 \mathrm{~min}$ and after a final rinse with PBS, the slides were mounted under glass coverslips with Gel/Mount (Permanent Aqueous mounting Medium) (Biomeda, USA). As a control, the primary antibody was omitted to exclude non-specific reactions.

The samples were then studied using the Nikon Eclipse E 400 microscope with the Nikon Y-FL epifluorescence attachment with the B-2A filter (excitation filter 450-498 nm, dichroic mirror $505 \mathrm{~nm}$ and barrier filter $520 \mathrm{~nm}$; Nikon, Tokyo, Japan). Microphotographs were taken by the Nikon digital camera DS-5MC using the NIS-elements AR imageanalyzer software (Laboratory Imaging, Prague, Czech Republic).

\section{Western blot analysis of MMP-13}

The cellular extracts (described above) were used for this analysis. After electrophoretic separation, proteins were electrotransferred to a nitrocellulose membrane in $15 \mathrm{mM}$ sodium borate buffer $(\mathrm{pH} 9.3)$ in Mini Trans-Blott Electrophoretic Transfer Cell (Bio-Rad Laboratories, USA) for $24 \mathrm{~h}$ at $4{ }^{\circ} \mathrm{C}$. Starting transfer power conditions were $25 \mathrm{~V} / 250 \mathrm{~mA}$, finishing conditions were $25 \mathrm{~V} / 350 \mathrm{~mA}$. Monoclonal antibodies to MMP-13 (prepared in our laboratory, see above) were diluted $1: 50$ in $2 \%$ skimmed milk-PBS and nitrocellulose membrane was incubated in this solution for $1 \mathrm{~h}$ at room temperature, and washed with $2 \%$ skimmed milk-PBS. The membrane was then incubated in a horseradish peroxidase (HRP)-conjugated swine anti-rat antibody solution diluted 1:500 for $1 \mathrm{~h}$ at room temperature. After washing, the membrane was stained with HRP substrate, 4-chloro-1-naphthol $(15 \mathrm{mg}$ in $5 \mathrm{ml}$ of methanol, $20 \mathrm{ml}$ of $10 \mathrm{mM}$ Tris- $\mathrm{HCl}, 0.04 \% \mathrm{H}_{2} \mathrm{O}_{2}$ ). The reaction was allowed to proceed in the dark for 15 min until all bands were visualized. The membrane was then air-dried.

\section{Zymography}

Cellular extracts with released enzymes were thawed at the room temperature and then the MMPs were analyzed by zymography (Novotná and Herget 1998). 


\section{A}

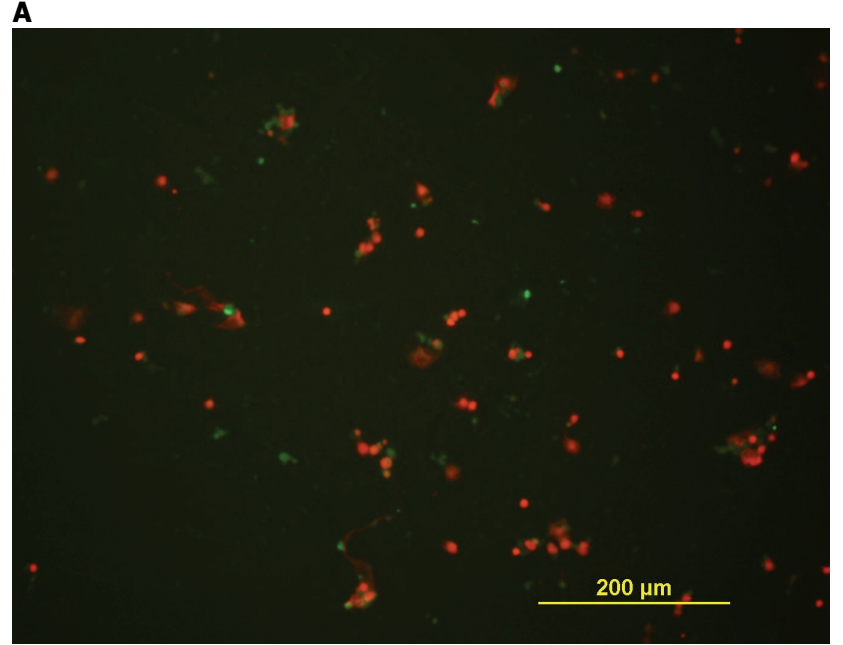

B

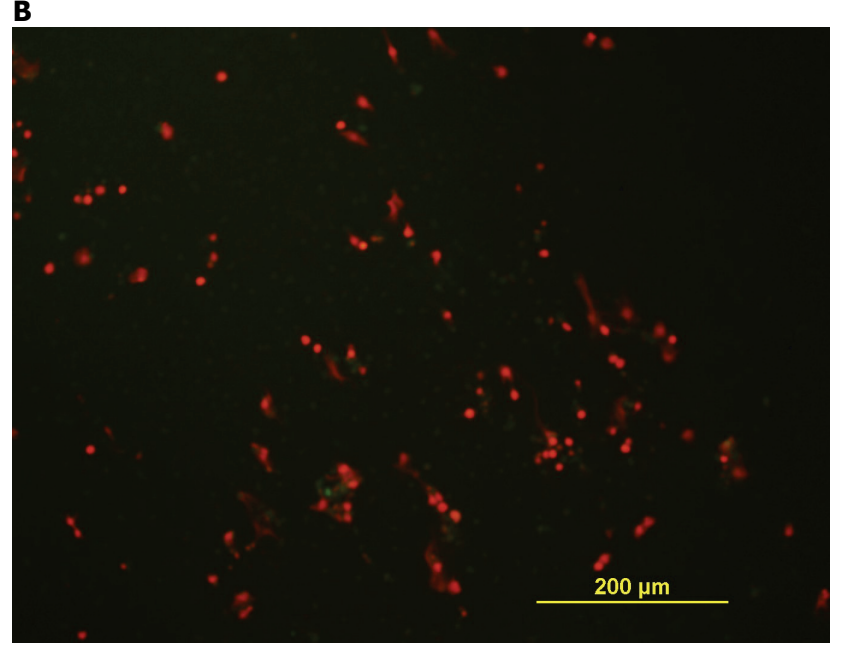

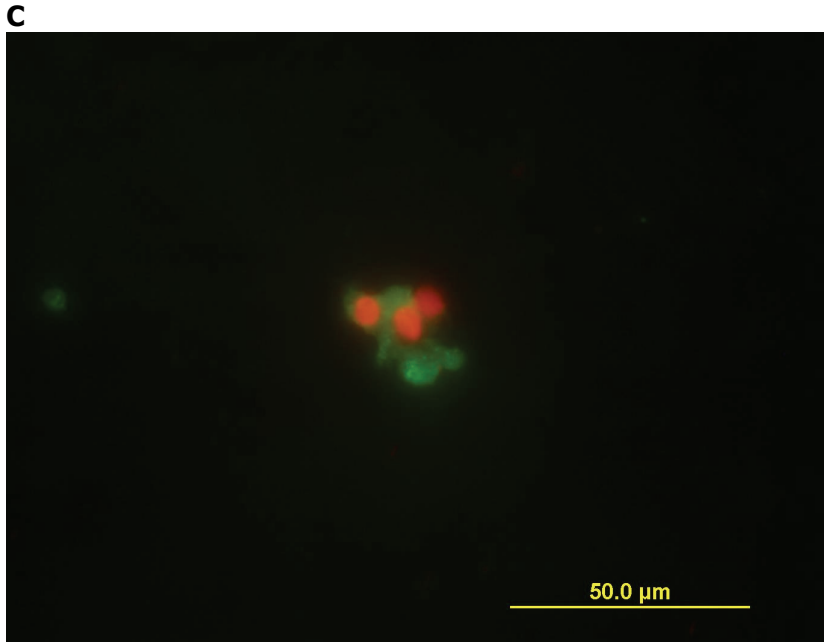

D

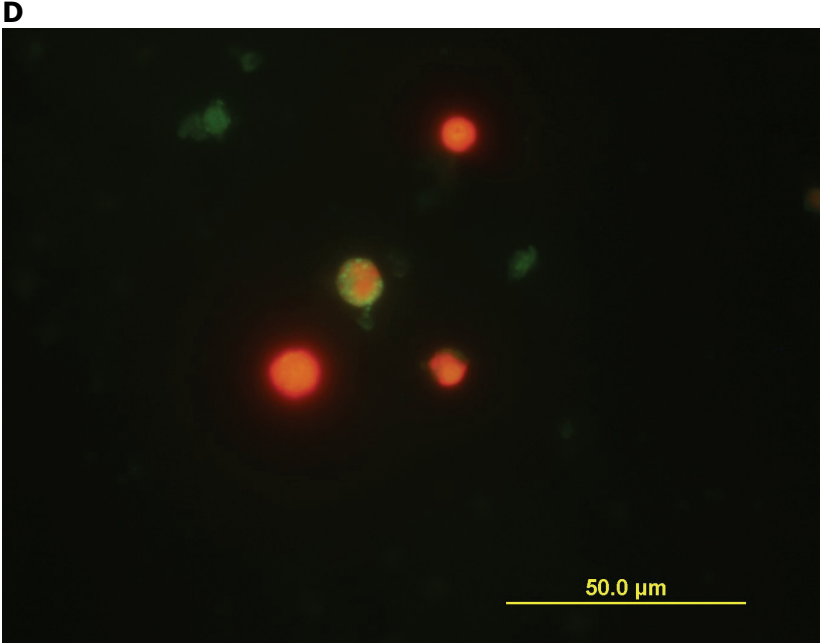

Fig. 1. Immunohistological characterization of MMP-13 (green) in isolated lung mast cells (red nuclei) using immunofluorescence labeling. LMC exposed for $24 \mathrm{~h}$ to hypoxia (A) show higher MMP-13 positivity against cells cultured in normoxic conditions (B). Details of two markedly positive MMP-13 labeled hypoxic LMC (C) and one positive MMP-13 labeled normoxic LMC (D).

Gelatin substrate was used; therefore the zymography preferentially targeted MMPs with gelatinolytic activity (MMP-2 and MMP-9). Proenzyme MMP-2, proenzyme MMP-9 (Oncogene Research Product) and high molecular weight calibration kit (Pharmacia Biotech) were used as standards.

\section{Enzymatic activity}

Mca-P-L-G-Ldpa-A-R-NH $\mathrm{N}_{2}$ fluorogenic peptide substrate I (R\&D Systems, Inc.) was used to measure the total MMPs activity. This peptide substrate can be cleaved by MMP-1, MMP-2, MMP-7, MMP-8, MMP-9, MMP-12 and MMP-13. Measurement of fluorescence was done by plate filter fluorimeter Genios (Tecan) with excitation at $340 \mathrm{~nm}$ wavelength and emission at $400 \mathrm{~nm}$. The final substrate concentration of reaction mixture was $1 \mu \mathrm{M}$ in $50 \mathrm{mM}$ HEPES buffer $\mathrm{pH} 7.4$ supplemented with
$10 \mathrm{mM} \mathrm{CaCl}{ }_{2}$ and $10 \mu \mathrm{M} \mathrm{ZnCl}_{2}$. Enzymatic activity was measured in both the cultivation medium as well as in cellular extracts. Enzymatic reaction was performed at $37^{\circ} \mathrm{C}$ and fluorescence was measured. Enzymatic activity was expressed in $\mathrm{pmol} / \mathrm{min} / \mathrm{ml}$.

Tryptase activity was assayed in the cultivation media and thawed cell lysates using the peptide substrate BAPNA (N- $\alpha$-benzoyl-DL-arginine p-nitroanilide hydrochloride, Sigma). Fifty $\mu$ of sample was added to $20 \mathrm{mM}$ Tris buffer ( $\mathrm{pH}$ 8.0) containing $1 \mathrm{M}$ glycerol and $7.77 \mathrm{nM}$ BAPNA. Absorbance was measured at $405 \mathrm{~nm}$ and tryptase activity was expressed in $\mu \mathrm{U} / \mathrm{min}$.

\section{Statistics}

Non-parametric Mann-Whitney test was used for statistical evaluation of the MMP-13-positive mast cells. Enzymatic activities were compared by ANOVA 


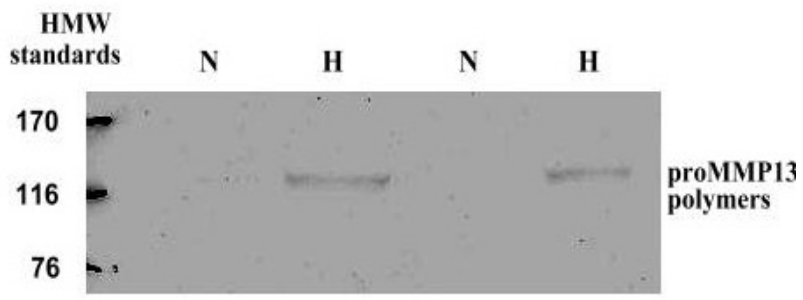

Fig. 2. MMP-13 detected by immunoblotting prevails in cellular extracts from LMC exposed to $24 \mathrm{~h}$ hypoxia.

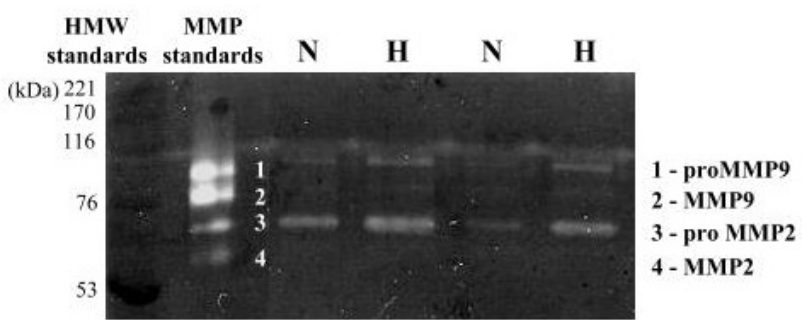

Fig. 3. Typical zymogram from the cellular extracts in groups of LMC cultivated $24 \mathrm{~h}$ in normoxic $(\mathrm{N})$ and hypoxic $(\mathrm{H})$ conditions.

(StatView 5.0, SAS Institute Inc., Cary, NC, USA). All data are presented as mean \pm S.E.M., differences was considered significant when $\mathrm{p}<0.05$.

\section{Results}

\section{LMC isolation}

We harvested from $0.65 \times 10^{6}$ to $1.2 \times 10^{6}$ mast cells with $90-95 \%$ vitality during one isolation. The purity of mast cells assessed by toluidine blue staining was $70-80 \%$. The major contaminating cell type was erythrocytes, which had a similar density as the mast cells.

\section{Immunohistochemistry}

We found significantly higher amount of cells labeled with monoclonal anti-rat MMP-13 antibody in group exposed to hypoxia $(\mathrm{H}: 19 \pm 3 \% ; \mathrm{N}: 3 \pm 1 \%$; $\mathrm{p}<0.05)$. Anti-MMP-13 immunofluorescence staining is shown on Figures 1A-D.

\section{Western blot}

Western blot analysis confirmed the presence of MMP-13 in the mast cells (Fig. 2).

\section{Zymography}

Zymography showed the lytic zones corresponding with standards of proMMP-9 and proMMP-2. Proenzymes outweighed the active forms, of

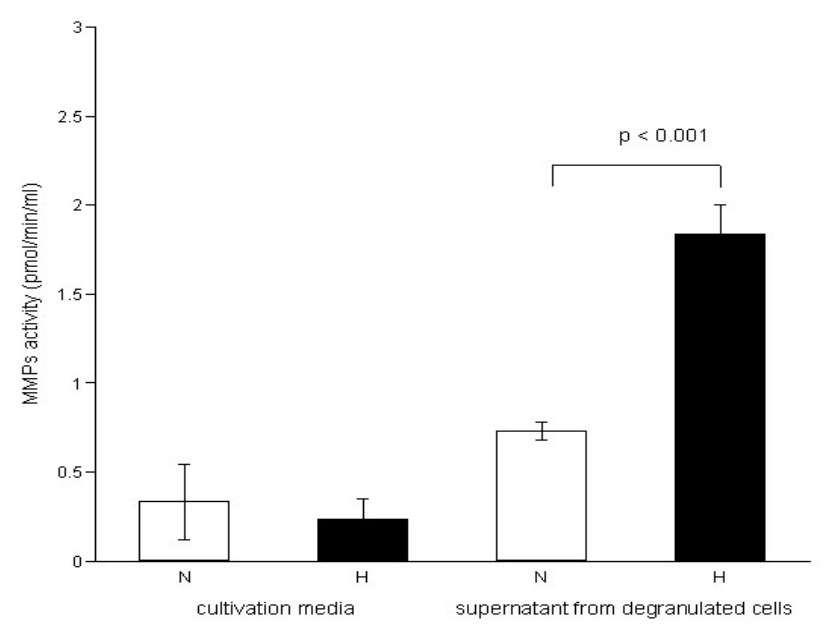

Fig. 4. Total MMPs activity (means \pm S.E.M.) assigned in cultivation media and cellular extracts (supernatant) in groups of cells cultivated $24 \mathrm{~h}$ in normoxic and hypoxic conditions (ANOVA, $p=0.0005$ ).

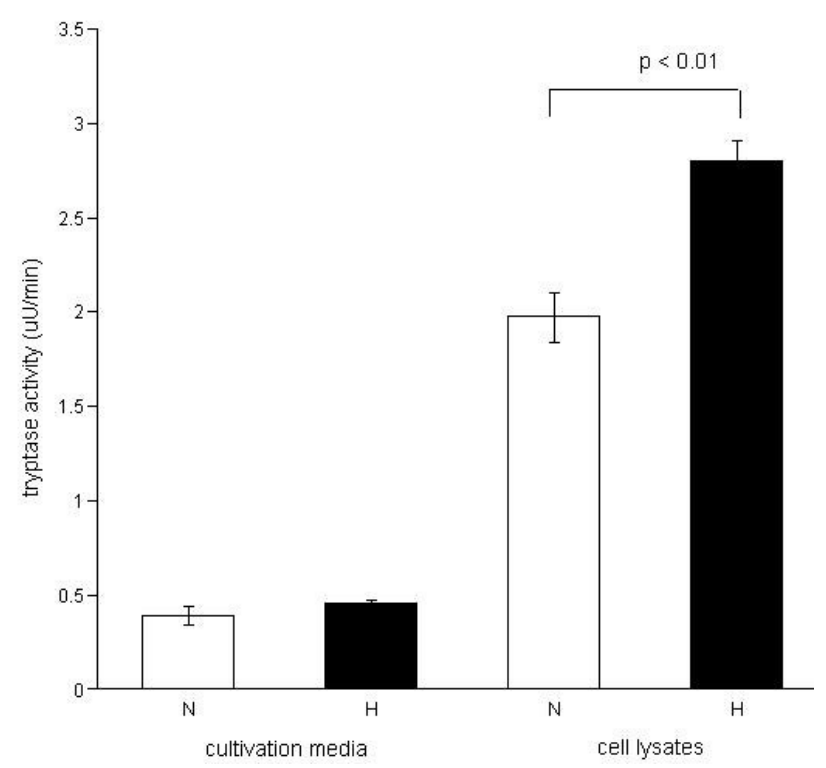

Fig. 5. Tryptase activity (means \pm S.E.M.) assigned in cultivation media and cell lysates in groups of cells cultivated $24 \mathrm{~h}$ in normoxic and hypoxic conditions (ANOVA, $p=0.004$ ).

which only MMP-9 was visible. The lytic zones of proenzymes were more transparent in cellular extracts obtained from LMC exposed to hypoxia (Fig. 3).

\section{Enzymatic activities}

Figure 4 demonstrates MMPs activity in cultivation media and in cellular extracts (supernatants). While MMPs activities of cultivation media in normoxic and hypoxic groups did not differ after $24 \mathrm{~h}$ of cultivation, the MMPs activity of cellular extracts was in hypoxic group significantly higher than in normoxic group. 
Figure 5 shows tryptase activity in cultivation media and in cell lysates. Tryptase activity of cultivation media did not differ between normoxic and hypoxic groups. Cell lysates from hypoxia-exposed cells showed significantly higher activity of tryptase than lysates from cells cultivated in normoxia.

Both MMPs and tryptase activities in cultivation media are expressed after deduction of activity of the control medium.

\section{Discussion}

In this study we found that rat lung mast cells exposed to $24 \mathrm{~h}$ of in vitro hypoxia showed higher activities of MMPs and tryptase than cells cultivated in normoxia. The results suggest that enzymes synthesized by lung mast cells can participate in the collagenolysis at the onset of remodeling of pulmonary vessels in chronic hypoxia.

The LMC were previously isolated from guinea pigs (Undem et al. 1985, Pele et al. 1989), bovines (Stahl et al. 1996), humans (Van Overveld et al. 1988) and rats with pulmonary fibrosis (Tomioka et al. 1989). The technique of LMC isolation was modified by Stahl et al. (1996) according to Enerback and Svensson (1980). The yield and vitality of isolated rat LMC in our present work are comparable with data described by Stahl et al. (1996).

Lung mast cells are an important source of collagenolytic and proteolytic enzymes as was described by others ( Tozzi et al. 1998, Edwards et al. 2005). It has been repeatedly shown that their number in the lung tissue increases in chronic hypoxia (Kay et al. 1974, Mungall 1976, Tucker et al. 1977, Williams et al. 1981). In an earlier quantitative morphological study we found the highest accumulation of LMC expressed MMP-13 in the wall of peripheral pulmonary arteries at the beginning of hypoxic exposure (Vajner et al. 2006).

Hypoxic pulmonary hypertension is adaptation and not continuously developing process. In the rat the changes of pulmonary vasculature develop in the first few days and after one week of exposure to hypoxia the hypoxic pulmonary hypertension fades into stable state with no sings of tissue radical injury (Hampl and Herget 2000). After two weeks of exposure the hypoxic pulmonary hypertension does not progress (Herget et al. 1978), and changes of collagen metabolism concern more conduit part of pulmonary vasculature (transmural vascular stress) than pathogenetically important resistance vessels. Treatment of hypoxic pulmonary hypertension with an antioxidant is effective at the beginning of exposure and without effect in steady state (Lachmanová et al. 2005).

The mast cells in the pulmonary tissue are under the control of many substances that may regulate their secretion. Our finding that hypoxia also stimulates MMP-13 formation in isolated LMC suggests that a mechanism mediating the increase of MMP-13 has to be intrinsic to mast cells. Two mechanisms or their combination may be considered. Hypoxia can stimulate release of a regulatory substance (e.g. cytokine) that would stimulate LMC by autocrine mechanism. The second alternative is that primary stimulus is hypoxiainduced oxidant stress. Siwik et al. (2001) described the increase of MMP-13, MMP-2 and MMP-9 activities in rat cardiac fibroblasts exposed to hydrogen peroxide and superoxide. We showed inhibitory effect of antioxidant $\mathrm{N}$-acetylcysteine on MMP-13 formation in the mast cells line RBL-2H3 exposed to hypoxia in vitro in our preliminary experiments (Maxová et al. 2004).

We demonstrated that hypoxia simultaneously stimulates a higher formation of tryptase in the mast cells exposed to hypoxia. Tryptase is a neutral protease considered as a marker of the mast cells activation (Hallgren and Pejler 2006). It also seems to be an important factor inducing mast cell chemotaxis (Berger $e t$ al. 2003). Tryptase can activate pro-MMPs, but it may also have direct effects on the extracelular matrix (Hallgren and Pejler 2006). Its fibrogenic action (Cairnsand and Walls 1997, Zhang et al. 1999) and gelatinolytic activity (Fajardo and Pejler 2003) in pulmonary vascular remodeling were described.

We selected the period of $24 \mathrm{~h}$ hypoxia, when LMC were still not degranulated, for two reasons: 1) from our recent study (Hodyc et al. 2007) we know that biochemical changes (oxidant tissue stress) develop within the first day of sojourn in hypoxia, and 2) it is technically impossible to harvest LMC from animals exposed to chronic hypoxia as the LMC before and after degranulation cannot be all at once separated by fractionation on Percoll column. However, mast cells degranulation seems to be in vivo an important process in hypoxia-induced pulmonary vascular remodeling, because prevention of mast cell degranulation (disodium cromoglycate administration) reduced development of hypoxic pulmonary hypertension (Kay et al. 1981, Baňasová et al. 2008). The degranulation therefore requires longer hypoxic exposure, and presence of other cell type or humoral factors. 
We conclude that lung mast cells exposed to hypoxia in vitro increase the MMPs and tryptase production. Enhanced MMPs and tryptase production may be related to the mechanism of pulmonary vascular remodeling in hypoxic pulmonary hypertension.

\section{Conflict of Interest}

There is no conflict of interest.

\section{Acknowledgements}

We thank Mrs. Alice Hezinová for technical assistance, and Eric Johnson, B.C. Pharm. (Department of Physiology, Second Medical School, Charles University) for the language revision of the manuscript. This work was supported by the Grant agency of the Czech Republic (No. 305/05/0672) and the Centre for Cardiovascular Research (No. 1M0510).

\section{References}

BAŇASOVÁ A, MAXOVÁ H, HAMPL V, VÍZEK M, POVÝŠILOVÁ V, NOVOTNÁ J, VAJNEROVÁ O, HNILIČKOVÁ O, HERGET J: Prevention of mast cell degranulation by disodium cromoglycate attenuates the development of hypoxic pulmonary hypertension in rats exposed to chronic hypoxia. Respiration 76: 102-107, 2008.

BERGER P, GIRODET PO, BEGUERET H, OUSOVA O, PERNG DW, MARTHAN R, WALLS AF, TUNON DE LARA JM: Tryptase-stimulated human airway smooth muscle cells induce cytokine synthesis and mast cell chemotaxis. Faseb J 17: 2139-2141, 2003.

CAIRNSAND JA, WALLS AF: Mast cell tryptase stimulates the synthesis of type I collagen in human lung fibroblasts. J Clin Invest 99: 1313-1321, 1997.

EDWARDS ST, CRUZ AC, DONNELLY S, DAZIN PF, SCHULMAN ES, JONES KD, WOLTERS PJ, HOOPES C, DOLGANOV GM, FANG KC: c-Kit immunophenotyping and metalloproteinase expression profiles of mast cells in interstitial lung diseases. $J$ Pathol 206: 279-290, 2005.

ENERBACK L, SVENSSON I: Isolation of rat peritoneal mast cells by centrifugation on density gradients of Percoll. J Immunol Methods 39: 135-145, 1980.

FAJARDO I, PEJLER G: Human mast cell beta-tryptase is a gelatinase. J Immunol 171: 1493-1499, 2003.

FREIJE JM, DIEZ-ITZA I, BALBIN M, SANCHEZ LM, BLASCO R, TOLIVIA J, LOPEZ-OTIN C: Molecular cloning and expression of collagenase-3, a novel human matrix metalloproteinase produced by breast carcinomas. J Biol Chem 269: 16766-16773, 1994.

HALLGREN J, PEJLER G: Biology of mast cell tryptase. An inflammatory mediator. FEBS J 273: 1871-1895, 2006.

HAMPL V, HERGET J: Role of nitric oxide in the pathogenesis of chronic pulmonary hypertension. Physiol Rev 80: 1337-1384, 2000.

HERGET J, SUGGETT AJ, LEACH E, BARER GR: Resolution of pulmonary hypertension and other features induced by chronic hypoxia in rats during complete and intermitent normoxia. Thorax 33: 468-473, 1978.

HODYC D, JOHNSON E, HNILIČKOVÁ O, HAMPL V, HERGET J: Reactive oxygen species production during chronic ventilatory hypoxia. FASEB J 21: A1287, 2007.

KAY JM, SUYAMA KL, KEANE PM: Mast cell stabilizing compound FPL 55618 reduces right ventricular hypertrophy and lung mast cell hyperplasia in chronically hypoxic rats. Experientia 37: 75-76, 1981.

KAY JM, WAYMIRE JC, GROVER RF: Lung mast cell hyperplasia and pulmonary histamine-forming capacity in hypoxic rats. Am J Physiol 226: 178-184, 1974.

LACHMANOVÁ V, HNILIČKOVÁ O, POVÝŠILOVÁ V, HAMPL V, HERGET J: N-acetylcysteine inhibits hypoxic pulmonary hypertension most effectively in the initial phase of chronic hypoxia. Life Sci 77: 175-182, 2005.

LI YY, MCTIERNAN CF, FELDMAN AM: Interplay of matrix metalloproteinases, tissue inhibitors of metalloproteinases and their regulators in cardiac matrix remodeling. Cardiovasc Res 46: 214-224, 2000.

MAXOVÁ H, NOVOTNÁ J, VAJNER L, VÍZEK M, VYTÁŠEK R, HERGET J: Effect of N-acetylcysteine on tissue metalloproteinases activity in RBL-2H3 mast cells exposed to 24 hours of "in vitro" hypoxia. Physiol Res 53: 24P, 2004.

MUNGALL IP: Hypoxia and lung mast cells: influence of disodium cromoglycate. Thorax 31: 94-100, 1976. 
NOVOTNÁ J, HERGET J: Exposure to chronic hypoxia induces qualitative changes of collagen in the walls of peripheral pulmonary arteries. Life Sci 62: 1-12, 1998.

NOVOTNÁ J, HERGET J: Possible role of matrix metalloproteinases in reconstruction of peripheral pulmonary arteries induced by hypoxia. Physiol Res 51: 323-334, 2002.

PELE JP, ROBIDOUX C, SIROIS P: Secretion of thromboxane $\mathrm{B}_{2}$ and prostaglandin $\mathrm{E}_{2}$ by guinea-pig lung cells isolated by centrifugal elutriation and by macrophages obtained by bronchoalveolar lavage. Pulm Pharmacol 2: 137-145, 1989.

SIWIK DA, PAGANO PJ, COLUCCI WS: Oxidative stress regulates collagen synthesis and matrix metalloproteinase activity in cardiac fibroblasts. Am J Physiol 280: C53-C60, 2001.

STAHL J, COOK E, DONG S, SABAN R, GRAZIANO FM: Isolation and purification of functional bovine lung mast cells (BLMCs). Zbl Veterinarmed B 43: 45-53, 1996.

TOMIOKA M, GOTO T, LEE TD, BIENENSTOCK J, BEFUS AD: Isolation and characterization of lung mast cells from rats with bleomycin-induced pulmonary fibrosis. Immunology 66: 439-444, 1989.

TOZZI CA, THAKKER-VARIA S, YU SY, BANNETT RF, PENG BW, POIANI GJ, WILSON FJ, RILEY DJ: Mast cell collagenase correlates with regression of pulmonary vascular remodeling in the rat. Am J Respir Cell Mol Biol 18: 497-510, 1998.

TUCKER A, MCMURTRY I, ALEXANDER AF, REEVES JT, GROVER RF: Lung mast cell density and distribution in chronically hypoxic animals. J Appl Physiol 42: 174-178, 1977.

TYAGI SC, CLEUTJENS JP: Myocardial collagenase: purification and structural characterization. Can J Cardiol 12: 165-171, 1996.

UNDEM BJ, GREEN F, WARNER T, BUCKNER CK, GRAZIANO FM: A procedure for isolation and partial purification of guinea pig lung mast cells. J Immunol Methods 81: 187-197, 1985.

VAJNER L, VYTÁŠEK R, LACHMANOVÁ V, UHLÍK J, KONRÁDOVÁ V, NOVOTNÁ J, HAMPL V, HERGET J: Acute and chronic hypoxia as well as 7-day recovery from chronic hypoxia affects the distribution of pulmonary mast cells and their MMP-13 expression in rats. Int J Exp Pathol 87: 383-391, 2006.

VAN OVERVELD FJ, TERPSTRA GK, BRUIJNZEEL PL, RAAIJMAKERS JA, KREUKNIET J: The isolation of human lung mast cells by affinity chromatography. Scand J Immunol 27: 1-6, 1988.

WILLIAMS A, HEATH D, HARRIS P, WILLIAMS D, SMITH P: Pulmonary mast cells in cattle and llamas at high altitude. J Pathol 134: 1-6, 1981.

ZHANG J, GRUBER BL, MARCHESE MJ, ZUCKER S, SCHWARTZ LB, KEW RR: Mast cell tryptase does not alter matrix metalloproteinase expression in human dermal fibroblasts: further evidence that proteolytically-active tryptase is a potent fibrogenic factor. J Cell Physiol 181: 312-318, 1999. 